\section{Human Rights Watch}

FOUNDED: 1978 as Helsinki Watch; 'Watch' committees throughout the world united in 1988 to form Human Rights Watch

OBJECTIVES: To end a wide range of abuses, including summary executions, torture, arbitrary detention, restrictions on the freedom of expression, association, assembly and religion, violations of due process, and discrimination on racial, ethnic and religious grounds
MEMBERS: The largest US-based human rights organizations supported by contributions from private individuals and foundations throughout the world; no government funds are accepted HEADQUARTERS: 350 Fifth Avenue, 34th floor, New York, NY 10118-3299, USA (telephone: +1 212 290 4700; fax: +1 212736 1300)

WEBSITE: http:/ / www.hrw.org

PUBLICATION: HRW World Report (annual) 